\title{
10. Cavell as Mentor
}

\section{SIANNE NGAI}

These remarks originally appeared in the Los Angeles Review of Books, January 5, 2012, and are reprinted here with the generous permission of the editors at the LARB.

I was a Grad student in English at Harvard in the mid-90s, but physically there for just three years, anxious to move to Brooklyn for a relationship as soon as I became ABD. In that brief but intense period of time, I tried to take as many courses offered by Stanley Cavell as possible. In my last year, I asked him to be a member of my dissertation committee. Looking back I'm still flooded with gratitude (and astonishment) by the fact that he said yes.

At the time I couldn't have said why I felt so attuned to Cavell's writing. I just knew, after reading his essay on moods in Emerson and Nietzsche ("Aversive Thinking”) and then his books on Thoreau and remarriage comedy (The Senses of Walden, Pursuits of Happiness), that I wanted to read more, and to think and talk with him as much as possible about the things he thought were interesting. All the more so when I realized that, in person, Stanley Cavell was exactly like the voice his writing projected. That voice, no matter what it happened to be speaking about-Shakespeare and the avoidance of love, Jacques Derrida and J. L. Austin, the Hollywood women's film of the 1930 s and 40s-was unfailingly generous and infectiously interesting. It was a meta-philosophical voice, preoccupied less with the wrongness of skepticism (that is, with skepticism understood as intellectual error, thereby capable of intellectual correction) than with its status as a basic condition of human life and also as a kind of madness, a denial of our shared reality with other minds. Cavell's voice was a kind of therapy against that madness. It was also an utterly and profoundly nonsnobby voice: the voice of a philosopher concerned with philosophy's aversion to the ordinary, and with the nondiscursive aspects of ordinary language-its affect and for- 
ce, its ontology as action-that seemed to interest so few other philosophers of language at the time. It was, finally and significantly, the voice of someone deeply interested in how gender inflects both of these problems.

I took four courses in a row with Cavell, all in the philosophy department: two graduate seminars on Lacan, an undergraduate lecture called "Aesthetics: Opera and Film," and a graduate seminar on King Lear. I loved these courses, even when I wasn't sure I understood what they were truly about. (It's called "Opera and Film," but what's it about really? I kept asking myself.) This was mostly due to my ignorance; I was still playing catch-up, in part by reading as much of Cavell's work as possible. But I think it was also due to the genuinely open and experimental nature of the courses Cavell taught. He was trying to work out certain questions in them, with us. This felt really thrilling.

"Opera and Film" was one of my favorites. The syllabus, as was always the case in Cavell's courses, was not so much eclectic as complex. We listened to and/or watched Carmen, Don Giovanni, Tannhäuser, The Lady Eve, Now Voyager, Moonstruck, Smiles of a Summer Night. We read J. L. Austin's How to Do Things with Words with Shoshana Felman's The Scandal of the Speaking Body: Don Juan with J. L. Austin, or Seduction in Two Languages, Catherine Clément and Susan McClary on women in opera, Baudelaire on Wagner, and selections from Cavell's own The World Viewed and A Pitch of Philosophy. Sometimes, delightfully, he would pause during a lecture, walk to the piano on stage, and play a passage or two from the score discussed in the reading. And as the semester progressed it became clear that what the course was "really about" was the peculiar ontology of what Cavell (adapting J. L. Austin) called passionate utterances: how they demand a response in kind, how words can be "owed," or thought of as a form of indebtedness to others. All of this was linked to the question of whether the split between words and music in opera was gendered, and to what became of the female voice in Hollywood melodrama.

Similarly, the grad seminar on King Lear was really about what Cavell called problematic praise, which was, in turn, another way to think about the complexities of aesthetic judgment and criticism. In addition to Shakespeare's tragedy, which foregrounds the consequences of false praise and ingratitude, we read Heidegger on 
thinking and thanking ("What is Called Thinking?") and Henry James's remarkable story about mass-cultural author worship ("The Birthplace”). One day Cavell showed us a scene from The Band Wagon (1953) in which Fred Astaire, as Cavell read it, tries to find a way to express his indebtedness to African-American dance. Cavell noted the way in which Astaire, a song and dance man, is shown, strangely, in 3/4 shot (cut off at the thighs) for the beginning of the film. It's not until after a routine in a penny arcade, in which Astaire does an extended duet with a black male dancer, that, as Cavell put it, pointing to his image on the screen, Astaire manages to "find his legs." Cavell read this performance as an act of praise, or as an expression of aesthetic indebtedness and gratitude; thinking also, as Cavell often did, about issues of race and appropriation, I wondered if it wasn't also readable as a kind of reparation or apology (which we often refer to as something "owed”). Both praise and apology belong to the class of what Austin called "perlocutionary" utterances, in which, as Cavell notes, the felicity of the action is dependent less on the "I" than the "you." In other words, if you do not accept my compliment or apology, then I haven't successfully complimented you or apologized.

Cavell's Lacan courses were more straightforward, organized around the French psychoanalyst's own famous seminars. The first, "Freud After Lacan," was on Book III: The Psychoses (Freud's reading of Daniel Schreber). The second, whose name I can't remember, was devoted to Book VII: The Ethics of Psychoanalysis (Kant, Sade, Antigone).

I was the only first-year English grad student in "Freud After Lacan." This made taking the course feel a bit lonely (so much of grad school is about learning alongside the people in your cohort) and that much more intimidating. It was Lacan, after all, and I didn't have a buddy to confide in, to talk with about my confusions. I was too much in awe of the philosophy Ph.D. students in the class, especially the many advanced ones in their fourth and fifth years, to make friends with them. Above all there was the difficulty of Lacan himself: those daunting quasi-mathematical algorithms, that sublime, inaccessible Real. But offsetting all of this was the fascinating question: What was it about Lacan (and Lacan's interpretation of Freud, in particular) that Cavell felt he had to grapple with philosophically? The fact that it was Stanley Cavell-someone who constantly wrote about language and gender, but who no- 
netheless was not on the chart of poststructuralists I'd been supplied with as an undergrad (a chart that included Lacan but not Cavell)-suddenly made Lacan all the more interesting.

In the classroom, Cavell was intense and serious, though often smiling. He had an amazing flash of a smile. While his syllabi were intricately structured, his pedagogy was open to the point that if he were struck by an issue in a text mentioned in someone's presentation, he would immediately revise the syllabus to assign that text in order to bring everyone else into the conversation. His way of thinking was explorative as opposed to combative, which is not to say that he never took issue with other thinkers. And though he was generous with his students, he didn't pretend to like everything they said. I once mentioned Theodor Adorno during a seminar, and Cavell, irritated but also showing a sense of humor about that irritation, said that Adorno always felt like a "flea in his ear."

In seminar I always tried to snag the seat right next to Stanley, on his left. (Mostly so I could hear him clearly; at the time I had a note-taking obsession, which involved transcribing every single word the professor said.) There was always a ring of auditors sitting around those of us at the table, and often these auditors were visiting from other countries. There were also professors and graduate students from various departments at BU and MIT. Once the philosopher Hilary Putnam was there; another time it was Stanley's wife. Cavell would talk first, in a directed but relaxed way, and student presentations on the reading followed. People worked really hard on the presentations, and they were almost always good. Somewhere in a file cabinet I still have all of their handouts about Freud and Lacan, including ones by Nancy Bauer (author of Simone de Beauvoir, Philosophy, and Feminism) and William Bracken (now in the philosophy department at UC Riverside).

I was inchoate and jelly-like in graduate school (kind of like a slime mold), but Cavell was kind to me anyway. He seemed to take me seriously. He gave me a lot of his time. Once, after having lunch together, he said to me, "You're very dutiful." The gentlest of criticisms. Of course, I-dutifully-tried to be less so.

We have stayed in touch, albeit loosely and intermittently, over the last seventeen years. Here's the last email I sent him: 


\section{Dear Stanley,}

Just a note to say hello and also how much I wish I could be at the conference on your work this October! (I committed myself to something else in Montreal on the same date, otherwise I ${ }^{* *}$ would $^{* *}$ be there).

I actually had a dream last night in which I ran into you at a dog park. (Do you have a dog?) The dogs were happily playing somewhere off on the field, and you asked, "Did you put your name on the list to get my family newsletter?” I hadn't. First thing I did when I woke up was to refind your email address on the internet, and that's when I found out about the conference. Which kind of **is** a family.

Best wishes to you,

Sianne

Stanley wrote back and said he did indeed have a dog, Kaya, who always stays by his side during his days of writing. He said he didn't have a family newsletter, but he did have an autobiography he was expecting to appear soon; if I sent him my address he'd send me a copy. 